\title{
Cash Flows and Financial Performance of Quoted Hospitality Firms in Nigeria
}

\author{
ThankGod C. Agwor PhD Igwe Ifeoma Beatrice \\ Department of Accountancy, Faculty of Management Sciences, Rivers State University, Port Harcourt.
}

\begin{abstract}
Managers of organizations that treat Cash flows as priority among other financial management issues are bound to achieve financial success. For the fact that cash is king in business, this investigation focused on Cash flows in relation to financial performance of quoted Hospitality / Tourism firm in Nigeria. Data were sourced from audited financial reports of ten (10) quoted Hospitality firms (2008-2017) and fact books of Nigerian Stock Exchange for the periods reviewed. Ordinary least square method was used to determine the extent to which cash flow management relates with financial performance of the selected hospitality and hospitality firms. After cross examination of the validity of the pooled effect, fixed effect and the random effect the study findings indicated that that there is no significant relationship between Cash flow from Operating Activities and Returns on Assets of hospitality firms in Nigeria. That there is significant relationship between Cash flow from Operating Activities and Net Profit Margin of hospitality firms in Nigeria. That there is significant relationship between Cash flow from Operating Activities and earnings per share of hospitality firms in Nigeria. Therefore, the study concludes that Cash flows has a moderate relationship with the financial performance of the quoted hospitality and tourism firms in Nigeria . Deriving from the conclusion, the study recommend that hospitality and tourism firms in Nigeria should set-up a result oriented cash flow system that will encourage the investing public to avail themselves of financial risk capable of not jeopardizing their investment and in order to restore the confidence of Nigeria investors and creditors the implementation of compulsory cash flow policies such as investment policy, dividend policy should be encouraged in the hospitality and tourism firms.
\end{abstract}

Keywords: Cash Flow, Financial Performance, Hospitality Firms, Net profit

DOI: $10.7176 / \mathrm{RJFA} / 12-2-03$

Publication date: January $31^{\text {st }} 2021$

\section{Introduction}

Handling Cash flows has become a critical element of many firms' operational strategies (Quinn, 2011). According to Efobi (2008) cash flow management plays a major role in the company's operations and financial performance. Cash flow management is the nucleus of a business entity for short and long-term financial performance (Uwonda \&Okello, 2013). A firm's cash flow management policies, which manage working capital in the form of cash receivables from customers, inventory holdings and cash payments to suppliers are widely linked to improved firm financial performance (Kroes \&Subramanyam, 2012).

Therefore, measuring the quality of any cash flow decision is to investigate the effect of such a decision on the fund's performance and on financial performance (Gill, Biger \& Mathur, 2011). Vahidet al.(2012) cited cash flow management as a determinant of success or failure of firms in business financial performance due to its effect on firm's profitability. Finance theory outlined that the ultimate goal of a company is to maximize shareholders wealth (Jensen, 2002); this is because shareholders provide funds to the company. Corporate profitability plays important role in the structure and development of a firm because it measures the performance and success of a firm. The profitability of an organization is affected by numerous factors. These factors include elements internal to each organization such as cash flow management and several important external forces shaping earnings performance (Akani \& Lucky, 2017).

The hospitality industry is a broad category of fields within the service industry that includes lodging, food and drinks services, transportation, cruise-lines, travelling, event-planning, theme-parks and additional fields within the tourism industry.The tourism / hospitality industry depends on the availability of leisure time and disposable income, holiday or vacation so to say. Hospitality and tourism units such as travelling, cruise-lines, restaurant,hotel or an amusement park consists of multiple groups such as facility maintenance and direct operations (servers, housekeepers, porters, kitchen workers, bartenders, management, marketing and human resources, etc.)

The financial performance is a combination of finance and performance. The financial aspect relates to money and management of money and the concept performance is derived from the term ,parfourmen ", which means, to do, to carry out" or "to render". It refers to the act of performance, execution, accomplishment and fulfillment. In wider sense, performance refers to the accomplishment of a given task measured against present standards of accuracy, completeness, cost and speed. According to Pandey (2010), the word "performance" is used to mean the efforts extended to achieve the targets efficiently and effectively. The achievement of targets involves the integrated use of human, financial and natural resources." In the words of Chandra (2005), "performance is a 
general term applied to a part or to all the conducts of activities of an organization over a period of time; often with reference to past or projected costs efficiency, management responsibility or accountability or the like." The financial performance is the blue print of the financial affairs of a business concern and, it reveals how a business has prospered under the leadership of its management. It shows the act of performing the financial activity of an organization. In other words, we can say whether the financial objective of the firm has been achieved or not. In broader sense, it is a process of measuring the result of a firm's policies and operations in monetary terms. The financial performance is also useful for measurement of the overall financial health of the organization over a given period of time. This technique also plays a vital role in comparison with other industries. The analysis of financial performance is not only confined to the quantitative traditional method that is ratio, cash flow statement or fund flow statements but also qualitative factors like efficiency and effectiveness. Performance indicate a problematic concept in terms of definition as well as quantification. It explains an output of an activity and the appropriate measure selected to assess the corporate performance in accordance with the objectives of the organization (Burca \& Batrinca 2014).

This study is poised to identify the relationship between Cash flows management and financial performance in hospitality industry. All Companies need the cash flow information in order to take better decision regarding their businesses and diagnose such symptoms as Solvency, Profitability and Operations information which are important factors to the management to take their decisions in other to achieve the company performance. Through such information, the organization assess its future ability to face challenges. This study main focus is on performance related issues that help to scan every aspect in business success. Therefore, we shall attempt to determine the outcomes of business performance / development due to intensity and effect of cash flows on business performance.

\section{Research Hypotheses}

The following null hypotheses were stated to guide the study:

$\mathrm{H}_{01}$ : There is no significant relationship between Cash flow from Operating Activities and Returns on Assets of hospitality firms in Nigeria.

$\mathrm{H}_{02}$ : There is no significant relationship between Cash flow from Operating Activities and Net Profit Margin of hospitality firms in Nigeria.

\section{Literature Review}

Al Hayek (2018) conducted a study on determining the relationship between sales revenue, net profit and cash flows from operating activities in Jordanian joint stock companies and from the study analysis, the result proved that net operating profit in relation to net cash flows from operating activities was statistically significant.

Nyabwanga, Ojera, Simeyo, and Nyanyuki (2013) investigated the liquidity, solvency, and financial health of selected small and medium-sized enterprises in the Kisii Municipality, employing ratio analysis as a means of financial diagnoses. Their study found that the understudied firms had low liquidity, low solvency, and poor financial health. It was also discovered that variables representing liquidity, solvency, and financial health exert a significant impact on the firms' performance measures.

Atieh (2014) focused on evaluating the liquidity of the pharmaceutical sector in Jordan using cash flow analysis. They found that some of the understudied firms had a good traditional liquidity ratio, while cash flow ratios tended to be weak. However, the cash ratios used in the study showed better positions of liquidity. The study, therefore, concluded that the liquid position of a firm is better represented by cash flow ratios than traditional ratios.

Robert and Hamacher (2015) investigated the effect of cash flow management on performance of mutual funds in America, concluded that the improvement in cash flows positively affected the financial performances measured by return on asset.

Amuzu (2010) studied cash flow as a measure of the performance of listed companies in emerging economies and found out that cash flow analysis measures the performance as well as competitiveness of firms appropriately. Mazloom, and Azarberahman (2013) analyzed the interrelationship between earnings, cash flow measures of performance and stock return in Nigeria. Secondary data collected over a period spanning from 2003 to 2011 were used in the study. Data collected in the study were analyzed using simple and multiple regression. The study revealed that a company's performance and cash flow have a significant negative relationship.

Amah, Ekwe, and Uzoma (2016) studied the relationship between free cash flow and operating earnings with the stock return and growth of net market values of operating assets in the Tehran stock exchange. The formulated hypotheses were tested using Pearson correlation and simple linear regression. The study revealed that there is a positive meaningful relationship between operating earning with return on equity, return on assets, and gearing of net market values in operating assets (Muneer et al., 2017).

Cheng, Cullinan, and Zhang (2014) conducted a study on the impact of free cash flow on performance using Chinese listed real estate firms and concluded that a negative relationship exists between them. Though the study 
utilised accounting profit, the author failed to include control for growth opportunities among firms. In addition, the study related free cash flow with contemporaneous profits, with no consideration for the overlapping effect. As a result, the study documented evidence that contradicts established free cash flow hypotheses.

Gregory (2005) investigated the effect of free cash flow on the performance of firms involved in mergers and revealed that mergers with a higher level of free cash flow perform better than those with low level of free cash flow.

Ashtiani (2013) carried out research work on the relationship between accounting ratios, operating cash flows, investments, financing, and stock returns in the Tehran Stock Exchange. The study sampled 650 quoted firms, covering a period between 1998 to 2004. Using techniques of analysis such as Pearson correlation and linear regression, the study showed that there is significant interrelationship among operating earnings, net profit, operating cash flows, investing cash flows, and stock returns; while the relationship that exists between growth of trade (sales) financing cash flows and stock return is not significant.

Taani and Banykhaled (2011) in their study investigated the effect of financial ratios, firm size and cash flow from operating activities on earnings per share. This study was performed on the 40 listed companies in the Amman Stock Exchange during the years 2000-2009. The research results indicate that there is positive and significant relationship between debt ratio, market value, operating cash flows and return on equity with earnings per share. There was no significant relationship between firm size and earnings per share.

Cheng et al. (2014) studied free cash flow, growth opportunities, and dividends of cross-listing of shares in China using multiple regression on 1105 randomly sampled companies over the period $2012-2016$. It was discovered that free cash flow exerts a significant impact on dividend payments of Chinese cross-listed companies, but doesn't for non-cross-listed companies.

Saez and Gutierrez (2015) provided evidence that free cash flow leads to an increase in dividend yield, and that the effect is stronger for low-growth firms. The study established that there is a significant positive relationship between the dividend policies and free cash flow of low-growth firms, but that the relationship tends to be insignificant for high-growth firms.

Nor Hasmadila (2014) studied the 100 largest listed companies in Bursa, Malaysia, by using panel data analysis and multiple regression models. The study revealed that there is positive interrelationship between free cash flow and the dividend pay-out of quoted firms in Malaysia. Stouraitis and Wu (2004)studied the ownership structure and dividend policy of Japanese firms with free cash flow problems.

Nwanyanwu (2015) carried out a study on cash flow and organizational performance of Nigerian Hospitality and Print Media using 45 small and medium enterprises from the two sectors. Data were collected and analysis were done through the means of descriptive statistics and Pearson product moment coefficient of correlations using SPSS. Variables of the study were Net Profit as the dependent variable and cash flow from operating activity as the independent variable. The result indicated that a significant strong positive relationship between cash flow position and net profit. Consequently, cash flow position determines the extent of net profit performance of organizations in the hospitality and print media.

Frank and James (2014) examined the relationship between cash flow and corporate performance in the food and Beverages sector of Nigeria. Data used were obtained from the Nigerian Stock Exchange for the period 2007 - 2011 and were analyzed using multiple regression technique. Return on Assets (ROA) represents the dependent variable and the three cash flow components as the independent variables. The study found that Operating and Financing Cash flows have significant positive relationship with corporate performance while investing cash flow and corporate performance have significant negative relationship. A study on the relationship between cash flow and profitability of small and medium enterprise in Nairobi was conducted by Guda (2013) for the period 2008 2012. Descriptive statistics was applied in this study using primary data obtained from individual small and medium enterprise firms. The data was organized into a panel, analyzed using a fixed effect regression model to obtain coefficients of the variables. The study revealed that there is a significant relationship between profitability and cash flow.

Ghanbari, et al (2015) conducted an investigation of cash flows' effect and financial performance of companies listed in Tehran Stock Exchange. Data from 183 companies were collected for the period 2009 - 2013 using statistical features such as efficiency, mean, standard deviation and regression analysis test, $\mathrm{t}$ test and Fisher F test to analyze on ROA as the dependent variable and Accounting cash flow (ACF), Equity Cash Flow (ECF), Free Cash Flow (FCF) and Capital Cash Flow (CCF) as the independent variables. It was found that there is a meaningful relation between accounting cash flow, equity cash flow, free cash flow, capital cash flow with financial performance of listed companies in Tehran Stock Exchange.

Mong'o (2010) analyzed the impact of cash flow on profitability in commercial banks in Kenya over the period from 2005-2009. It was specifically conducted to explain the influence that various components of cash flows have on profitability growth. Multiple regression models were used to analyze the data and the findings of the study indicate that Cash flow from the financing and the investing activities have a great positive influence on the banks' profit while operating cash flow has a negative effect. 
Gheshlaghi, Ahamdzadeh and Faal (2014) carried out a study on the cash flow statement component effect on management performance using 138 firms listed on the Tehran Stock Exchange for the period of 5 years, 2008 - 2012. Using multiple linear regressions on the variables Return on Assets (ROA) and Operating Cash Flow And Corporate Financial Performance Of Listed Conglomerate Companies, return on equity (ROE) as performance measures and the independent variables Cash flow from Financing activities (CFF), Cash flow from Investing activities (CFI), Cash flow from Operating activities (CFO) and Cash flow from Return on Investment and Interest paid to finance (CFRI\&SF). The research finding shows that there is negative relationship between cash flows from investments activities and return on assets. Also, there is no relationship between cash flows from operational activities, financing activities and return on assets.

Tariverdi, Amanolahi and Faal (2014) also conducted a study on the effects of components of a part model of cash flow statement on operational performance of listed Tehran Stock Exchange. All firms enlisted in the Stock Exchange were included in a time range of 5 years from 2007 - 2011. The DVs ROA and ROE and Cash flows resulting from investments' return (CFIR), Cash flows resulting from interest paid for financing (SF), Cash flows of investment (CFI) and Cash flows of financing (CFF) were analyzed using Pearson correlation. The study revealed that there is positive relationship between CFIR and ROA and ROE, a negative relationship between $\mathrm{SF}$ and ROE and no meaningful relation between CFI, CFF and ROA and ROE.

Ojode (2014) studied the effect of free cash flow on profitability of firms listed for the period $2009-2013$ on 30 sampled firms. Using Pearson correlations on data revealed that there is a strong negative relationship between free cash flow and profitability of listed firms. From the empirical studies reviewed, it has been found that there is no consistency in the use of variable, sector and economy thereby resulting to diversified outcome.

Ghanbari et al (2015) opined that cash flow can decrease the risk related to operations thereby leading to an increase of companies' performance and Guda (2013) opined that a company generating healthy cash balances will invariably have a high financial performance. Hence, cash flow is absolutely critical for the existence and survival of an organization.

Bhunia, Khan and Mukhuti (2011) empirically studied the relationships between liquidity, solvency of firms and profitability. The study employed data from the audited annual reports of the selected private sector steel firms listed on Indian Stock Exchange. The sample was drawn using purposive sampling technique and covered a ten (10) year period (1997 - 2006). The

four companies selected are Tata steel limited, Lloyds steel industries Limited, Kalyane Steels Limited and JSW steel Limited. The independent variables : current ratio, liquid ratio, absolute liquid ratio, short term debt equity ratio, age of inventory, age of debtors and age of creditors are regressed against profitability of the sampled firms proxied by return on investment. All the variables passed the normality (approaching normal distribution that is bell - shaped) tests carried out using the Shapiro - Wilks' test and Lillifors test. The study indicated that liquidity and profitability are strongly positively related with a multiple correlation coefficient of 0.934 .

Uremadu and Efobi (2009) investigated empirically the relationships between capital structure, liquidity and the dependent variable: corporate profitability in Nigeria. The study adopted pooled ordinary least square regression technique on a sample of 10 firms for the five year period $(2002-2006)$. The technique made use of $\log$ - linear least squares for analysis of collated data. The study showed negative but statistically significant relationships between ratios of long term debt to total liability, short-term debt to total liability, equity capital to total liability and profitability. It also showed a positive and statistically significant relationship between the domestic liquidity rate and profitability, ratio of long - term debt to equity capital, total value of short term debt and profitability.

Nyabwanga, Otieno, \&Nyakundi (2013) in their study of the relationship between liquidity, solvency and financial health of small and medium - sized enterprises (SMEs) in Kisii Municipality, Kenya identified unsound financial management, inadequate working capital, slow conversion of receivables and inventory into cash and cash equivalents, increasing trade debts and low turnover as causes of low or average performance of these firms. The study adopted ratio analysis method in analyzing secondary data collated from the audited annual accounts and the accompanying schedules of three SMEs. The study spanned for three years $(2009-2011)$. Further analysis included measures of central tendencies and dispersion such as the arithmetic means, standard deviation, coefficient of variation, and the Altman's Z - score model. Independent variables used are made up of current ratio, quick ratio and debts to total assets ratio while the dependent variables are return on asset (ROA), gross operating profit (GOP) and net operating profit (NOP). The study concurred that the current and quick ratios of the sampled firms are below industrial average of 2:1 and 1:1 respectively. Therefore, the SMEs are not capable of honoring debt obligations as they fall due. These SMEs employ aggressive financial policy and risks of insolvent are quite high for two out of the three firms.

Bolek and Wolski (2012) carried out a study on the impact of liquidity and profitability on the market value of firms using companies listed on the Warsaw Stock Exchange. The study investigated the relationships between cash, account receivables, inventories, account payables and profitability using ratios. The study claimed that dynamic management in firms entails ascertaining profitability using economic value added (EVA) and liquidity 
proxied by CCC. The study covered a ten year period $(2000-2009)$ and purposefully selected a sample of 69 firms resulting in 690 observations. Collated data were analyzed using Pearson Product Moment Correlation and evaluation done using $\mathrm{t}$ - test. It was observed that profitability is much more vital to Polish firms than liquidity in firm valuation. However, investors prefer firms that maintain high level of cash in the Polish market in that the lower the CCC, the greater t Tobin's q. In other words, reasonable reductions in inventory and accounts receivable periods have strong influence on firm performance. Moreover, univariate analysis suggests that reductions on accounts receivable period enhance profitability of firms.

Almeida, Campello, Cunha and Weisbach (2013) studied frame works of corporate liquidity management. They postulated that problems of managing liquidity in firms can be solved if a convergent framework from series of frameworks since Keynes (1936) evolves. In other words, precautionary demand for money / liquidity is the trigger for the variations in the level of liquidity of firms. Their model centered on the impact of liquidity on real policies of companies. They

noted that the relevance of liquid derivatives has been accentuated by the global financial crises (GFC) of $2008-2009$. Cash, being the real liquid resource, is most sought for by firms, in that it is the surest way of meeting up future investment needs.

\section{Methodology}

The study adopted the quasi experimental research design .Data analysis was carried out with the aid of E-view version 9.0. The population of the study is made up of all the quoted hospitality firms in Nigeria as at December,2018. From the records of the Nigeria Stock Exchange there are 10 companies listed in the hospitality and tourism sector of the NSE as at December, 2018. Since the firms were 10 in number and less than 30 that is, $\mathrm{n}<30$, the study census include all the ten firms.

\section{Results}

Test of Hypotheses 1

Ho1: There is no significant relationship between Cashflow from Operating Activities and Returns on Assets of hospitality/tourism firms in Nigeria.

Table 4.8: Test of hypothesis I

\begin{tabular}{ll} 
T calculated & -0.031305 \\
T table & 1.080 \\
Significant level & $5 \%=0.025$ (two tail) \\
Probability & 0.9751 \\
\hline
\end{tabular}

\section{Source: E-view 9.0}

Decision

With computed $t$ value of \pm-0.031305 less than the critical $t$ value of 1.080 the researcher therefore reject the alternate hypothesis and accept the null which says that there is no significant relationship between Cash flow from Operating Activities and Returns on Assets of hospitality/tourism firms in Nigeria

Test of Hypothesis 2

Ho2: There is no significant relationship between Cash flow from Operating Activities and Net Profit Margin of hospitality/tourism firms in Nigeria.

Table 4.9: Test of hypothesis II

\begin{tabular}{ll}
$\mathrm{T}$ calculated & -1.339901 \\
$\mathrm{~T}$ table & 1.080 \\
Significant level & $5 \%=0.025$ (two tail) \\
Probability & 0.0038 \\
\hline
\end{tabular}

Source: E-view 9.0

\section{Decision}

With computed $t$ value of \pm-1.339901 greater than the critical $t$ value of 1.080 the researcher therefore reject the null hypothesis and accept the alternate which says that there is significant relationship between Cash flow from Operating Activities and Net Profit Margin of hospitality firms in Nigeria.

\section{Discussion of Findings}

The regression coefficient found that operating cash flow has negative and insignificant impact on the return on assets of the quoted hospitality firms in Nigeria. The beta coefficient of -0.031305 as parameter for operating cash flow proved that a unit increase on the variable will lead to 0.3 percent decrease on return on assets of the quoted hospitality firms in Nigeria. However, the hypotheses formulated were tested using the t-statistics and the 
probability coefficient from the fixed effect model validated by the Hausman test. The t-statistics of -0.9751 at 5 percent level of significant which implies that there is no significant relationship between operating cash flow and return on assets of the selected quoted hospitality firms in Nigeria within the periods covered in this study. The negative insignificant effect of operating cash flow on return on assets implies that increase or decrease on the variable will not have any meaningful effect on the dependent variable. This finding confirms the findings of Ali, et al (2013) that company's performance and cash flow have a significant negative relationship; furthermore, earning based measures are more related to stock returns and depict the company performance better than cash flow measures in some companies with higher accruals.

The objective to examine the relationship between Cash flow from Operating Activities and Net Profit Margin of hospitality firms in Nigeria indicated that the regression coefficient found that operating cash flow has negative and insignificant impact on the net profit margin of the quoted hostility firms in Nigeria. The beta coefficient of 1.339901 as parameter for operating cash flow proved that a unit increase on the variable will lead to 13 percent decrease on net profit margin of the quoted hospitality firms in Nigeria. However, the hypotheses formulated were tested using the t-statistics and the probability coefficient from the fixed effect model validated by the Hausman test. The t-statistics of 0.0038 at 5 percent level of significant which implies that there is significant relationship between operating cash flow and net profit margin of the selected quoted hospitality firms in Nigeria within the periods covered in this study. The negative insignificant effect of operating cash flow on net profit margin implies that increase or decrease on the variable will have meaningful effect on the net profit margin.

The objective to examine the relationship between Cash flow from Operating Activities and Earnings per Share of hospitality firms in Nigeria however, indicated that the regression coefficient found that operating cash flow has negative and significant impact on the earnings per share of the quoted hostility firms in Nigeria. The beta coefficient of -1.298223 as parameter for operating cash flow proved that a unit increase on the variable will lead to 12 percent decrease on earnings per share of the quoted tourism firms in Nigeria. The negative insignificant effect of operating cash flow on return on assets implies that increase or decrease on the variable will have meaningful effect on the net profit margin. The negative insignificant effect of Cash flow from Investing Activities on return on assets implies that increase or decrease on the variable will have meaningful effect on the return on assets.

\section{Conclusion and Recommendations}

In conclusion, the Cash flows has a moderate relationship with the financial performance of the quoted hospitality and tourism firms in Nigeria. Premising from the study findings, the following recommendations are presented:

1. Hospitality and tourism firms should set-up a result oriented cash flow system that will encourage the investing public to avail themselves of financial risk capable of not jeopardizing their investment.

2. Implementation of compulsory cash flow policies such as investment policy and Dividend policy should be encouraged in the hospitality and tourism firms in order to restore the confidence of Nigeria investors and creditors.

\section{REFERENCES}

Abioro, M. A. (2013) The impact of cash management on the performance of manufacturing companies in Nigeria. Uncertain Supply Chain Management, 1, 177 - 192.

AclanOmag (2016) Cash Flows from Financing Activities.Evidence from the Automotive Industry.International Journal of Academic Research in Accounting, Finance and Management SciencesVol.6,No.1,January2016,pp. $115-122$

Adelegan, O.J. (2003). An Empirical Analysis of the relationship between cash flow and Divided charges in Nigeria. Journal of Research in Development and Management, 1(5),35-49

Agbada, A. O. \&Osuji, C. C. (2013). The efficacy of liquidity management and banking performance in Nigeria.International Review of Management and Business Research, 2 (1), 223 - 233.

Akinbuli, S. F. (2009) Cash management techniques and application for corporate organization.The Nigerian Accountant, 42 (1), $27-33$.

Alireza, A \& Jalal, .A. (2013). The association between various Earnings and cash flow measures of firm performance and stock returns: some Iranian evidence. International journal of accounting and financial reporting. 3. No 1. $24-39$.

Al Hayek, M.A.(2018). The Relationship Between Sales Revenue and Net Profit with Net Cash Flows from Operating Activities in Jordanian Industrial Joint Stock Companies,International Journal of Academic Research in Accounting, Finance and Management Sciences 8 (3): 149-162.

Al ShahreniSaad (2016). The impact of Organizational factors on financial performance. International Journal of Management Science and Business Administration.Vol 2. Issue 7

Alshattu, A. S. (2015). The effect of the liquidity management on profitability in the Jordanian commercial banks.International Journal of Business and Management, 10 (1), $62-71$. 
Altman, E. I. (1983). The success of business failure prediction models: An international survey. Journal of Banking \& Finance, 8(2), 171-198.

Amah, K. O., Michael, C. E. \&Ihendinihu, J. U. (2016). Relationship of cash flow and financial performance of listed Banks in Nigeria. European Journal of Accounting, Auditing and Finance Research. 4(4), 89 - 97

Boyd, T. \&Cortese-Danile, T. M (2000).Using the Cash Flow Statement to Improve Credit Analysis. Commercial Lending Review, Winter, v. 16, n. 1, p. 55-59.

Bruwer, J.P. (2015). The Usefulness of Cash Budgets in Micro, Very Small and Small Retail Enterprises Operating in the Cape Metropolis. Expert Journal of Business and Management, 3 (1), 1-12. 5.

Chikashi, T O. (2013). An Investigation of comprehensive income and firm performance: The case of the electric appliances Industry of the Tokyo Stock Exchange. Journal of Accounting and finance research. 2. No2, 2935.

DeFranco, A. L. \&Schmidgall, R. S. (1998). Cash flow practices and procedures in the

lodging industry. Journal of Hospitality \& Tourism Research, 22(1), 72-83.

Efobi, R. U (2008). The Impact of Capital structure on corporate profitability in Nigeria.An unpublished M.Sc Dissertation submitted in impartial fulfillment for the Award of an M.Sc Degree in Accounting, Department of Accountancy, CBS, CU, OTA, Ogun State.

Egbide, B. C., Uwuigbe, O. \&Uwalomwa, U. (2013).Liquidity management and profitability of manufacturing companies in Nigeria.IOSR Journal of Business and Management, 9 (1), 13 - 21.

Graham, J.R., Campbell, R. H. \&Rajgopal, S. (2004), The economic implications of corporate financial reporting. Working paper, 11 January.

Gyebi, F., Quain, S. (2013).Internal Control on cash collection.A case of the electricity company of Ghana ltd, Accra East region.International Journal of Business and Social Science, 4 (9), 217-233 10.

Heydari, I., Mirzaeifar, M. \&Javadghayedi, M. (2010).Investigating the relationship between free cash flow and the firm performance: Evidence from Tehran Stock Exchange. Indian Journal of Science and Research, Vol. $4(6), 269-279$

Jeter, D. C. (2005).Using the Statement of Cash Flows. Commercial Lending Review,Vol.20, Issue 4, July-August, $3-10$.

John Wiley \& Sons. Almeida, H., Campello, M., Cunha, I. \&Weisbach, M. S. (2013). Corporate liquidity management: A conceptual framework and survey. Journal of Finance Forthcoming, 2 (2), 67 - 78.

KisangRyu\&Soocheong Jang (2004). Performance Measurement Through Cash Flow Ratios and Traditional Ratios: A Comparison of Commercial and Casino Hotel Companies. Journal of Researchgate publication Article DOI: 10.1080/10913211.2004.10653783

Mills, J. R., \& Yamamura, J. H. (1998). The power of cash flow ratios.Journal of

Accountancy, 186(4), 53-62.

Muhammad Liman and AminatuSani Mohammed (2018). Operating Cashflow and Corporate Financial performance of listed conglomerate companies in Nig. IOSR Journal of Humanities and Social Science.vol 23 , issue 2

MurkorAbiudSoet el al (2018). Effect of Operating Cash flow Management on Financial Performance of mutual funds in Kenya. European Journal of Business, Economics and Accountancy. Vol. 6, No 5

Ngary, C., Smith, Y., Bruwer, J.P. and Ukpere, W.I. (2014). Financial performance measures and business objective attainment in Fast Food SMMEs in Cape Metropolis: A preliminary liability and suitability analysis. Mediterranean journal of social science, 5 (20), 909-919. 14.

Niskanen, J. \&Niskanen, M. (2006). The determinants of corporate trade credit policies in a bank-dominated financial environment: the case of Finnish small firms. European Financial Management, 12 (1), 81 - 102.

Nwankwo, O. and Osho, G. S. (2010). An empirical analysis of corporate survival and growth: Evidence from efficient working capital management. International Journal of Scholarly Academic Intellectual Diversity, 12 (1), $1-13$

Nwanyanwu, L. A. (2015). Cash flow and organizational performance in Nigeria: Hospitality and print media industries perspectives. European Journal of Business, Economics and Accountancy. 3 (3), 66-72

Ojode, C. A. (2014). Effect of free cash flow on profitability of firms listed on the Nairobi securities exchange. A research project submitted for the award of degree of masters of business administration. School of Business, University of Nairobi

Okafor, R. G. (2012). Financial management practices of small firms in Nigeria: Emerging tasks for the accountant. European Journal of Business and Management, 4 (114), 159 - 169.

Onuoha, B. C. (2012). The Environments of the Manufacturing Sector in Nigeria: Strategies Towards Vision 2020. International Business and Management, 5 (1), 67-74.

Onwioduokit, A. and Nwachukwu, J. (2008).Financial ratios and the probabilistic prediction of bankruptcy.Journal of Accounting Research 18(Spring): 109-131

Orhan, A \&Basar, A.B. (2015). IsletmelerdeNakitAkisProfilleriveAnalizi: $\quad$ BIST 100 
IsletmeleriUzerineBirUygulama. MuhasebeveVergiUygulamalarıDergisi, 8 (2), 107-122.

Owolabi, S. A. \&Obida, S. S. (2012). Liquidity management and corporate profitability: A case study of selected manufacturing companies listed on the Nigerian stock exchange. Business Management Dynamics, 2 (2), 10 -25 .

Pouraghajan, A., Tabari, N. A. Y., Mansourinia, E. \&Emangholipour, M. (2013). The effect of free cash flows and Agency cost on performance of listed companies in Tehran Stock Exchange. World of Science Journal, 1 (6), $1-10[19]$.

Velnampy, T. \&Kajananthan, R. (2013).Cash Position and Profitability of Telecommunication Sector in Srilanka.Greener Journal of Social Sciences, 3 (6), 324 - 333

Zeller, T. L., \&Stanko, B. B. (1994). Operating cash flow ratios measure a retail firm's ability topay.\| Journal of Applied Business Research, 10(4), 51-59.

Zhou, H, Yang, S. and Zhang, M (2012).Relationship between free cashflow and financial performance.Evidence from the Listed Real Estate Companies in China. IPC.SIT. 36; 331-335 